\title{
PENERAPAN PEMBELAJARAN CTL UNTUK MENINGKATKAN HASIL BELAJAR MENULIS CERPEN
}

\author{
Ida Hayani ${ }^{1}$, Busmin Gurning ${ }^{2}$, Samsidar Tanjung ${ }^{3}$ \\ ${ }^{1}$ Sekolah Menengah Atas Negeri 1 Perbaungan, Sumatera Utara \\ ${ }^{2,3}$ Program Pascasarjana, Universitas Negeri Medan, Medan \\ ${ }^{1}$ Ida_hayani@gmail.com; ${ }^{2}$ profbusmingurning@gmail.com ${ }^{3}$ samsidar.tanjung55@gmail.com
}

\begin{abstract}
Abstrak: Penelitian ini merupakan penelitian tindakan kelas yang bertujuan untuk menerapkan strategi pembelajaran Contextual Teaching and Learning (CTL) yang dapat meningkatkan hasil belajar menulis cerpen bagi siswa. Tempat penelitian dilakukan di kelas XI IPS-2 SMA Negeri 1 Perbaungan. Cara penelitian dilakukan dalam dalam dua siklus yang masing-masing terdiri dari siklus pertama tiga kali pertemuan dan siklus kedua tiga kali pertemuan. Setiap siklus terdiri dari tahapan perencanaan (planning), tindakan (acting), pengamatan (observation), dan refleksi (reflecting). Jumlah partisipan dalam pelaksanaan siklus masing-masing 40 orang siswa. Pengumpulan data dilakukan melalui tes hasil belajar menulis cerpen siklus I dan siklus II, observasi langsung terhadap aktivitas siswa dalam belajar berkelompok. Hasil penelitian menunjukkan bahwa Pembelajaran pada siklus I belum memcapai Kriteria Ketuntasan Minimal (KKM) dengan perolehan nilai rata-rata subjek penelitian 61.00 menurut penilai 1 dan 59.51 menurut penilai 2. Pembelajaran pada siklus II, nilai pembelajaran sudah berhasil memenuhi Kriteria Ketuntasan Minimal (KKM) dengan nilai rata-rata subjek penelitian mencapai 78.20 menurut penilai 1 dan 79.65 menurut penilai 2. Aktivitas siswa dalam belajar kelompok pada siklus I masih rendah karena siswa belum terbiasa melakukan kegiatan berkelompok, tetapi pada siklus II mulai meningkat.
\end{abstract}

Kata Kunci: ctl, hasil belajar, menulis cerpen

Abstract: This is an action research which is aimed to implement The Contextual Teaching and Learning (CTL) strategies that can improve students' learning achievement in writing short stories. The research was conducted at XI grade IPS-2, SMA Negeri 1 Perbaungan. The research was done in two cycles in which each cycle consists of three meetings. Each cycle consists of stages, namely: planning, action, observation, and reflection. The number of the participants in each cycle was 40 students. The data were collected by using the students' achievements in writing short stories at cycle I and II and also direct observation of students' activities in group learning. The results of the research showed that the students' achievements at cycle I have not reached the Minimum Completeness Criteria with the acquisition of the average value is 61.00 point based on assessor 1 and 59.51 based on assessor 2. But at cycle II, the average value of students' achievements already successfully reach the Minimum Completeness Criteria with the average value of research subjects reached 78.20 based on assessor 1 and 79.65 based on assessor 2. Students' activities in group learning at cycle I was still low because most of the students were not familiar at doing group activities but they began to increase at cycle 2.

Keywords: ctl, learning outcomes, writing short stories

\section{PENDAHULUAN}

Pendidikan masa kini menuntut guru bukan hanya sebagai sumber belajar saja, melainkan dapat pula berperan sebagai fasilitator, pengelola, demonstrator, pembimbing, motivator dan evaluator (Sanjaya, 2010:21). Guru sebagai sumber belajar sebaiknya menguasai materi pelajaran dengan baik. Sebagai fasilitator guru memberikan pelayanan untuk memudahkan siswa dalam kegiatan proses pembelajaran. Peran sebagai pengelola dapat dilakukan guru dengan cara menciptakan iklim belajar yang kondusif sehingga memungkinkan siswa dapat belajar dengan nyaman. Sebagai demonstrator, ada dua hal yang dilakukan guru, (1) harus menunjukkan sikap terpuji dalam setiap aspek kehidupan, (2), menunjukkan bagaimana 
caranya agar materi pelajaran bisa lebih dipahami dan dihayati oleh setiap siswa. Peran pembimbing dilakukan guru untuk membimbing siswa agar menemukan berbagai potensi yang dimilikinya sebagai bekal hidup yang menjadi harapan masyarakat,.sebagai motivator guru haruslah menumbuhkan motivasi belajar siswa untuk memperoleh hasil belajar yang optimal. Sebagai evaluator guru mengumpulkan data atau informasi tentang keberhasilan pembelajaran yang telah dilakukan. Fungsi evaluasi adalah untuk menentukan keberhasilan siswa dalam menyerap materi pelajaran dan untuk menentukan keberhasilan guru dalam melaksanakan seluruh kegiatan yang sudah diprogramkan.

Berdasarkan kenyataan di atas, proses pembelajaran yang ideal adalah proses pembelajaran yang memperhatikan perubahan tingkah laku, baik aspek tingkah laku kognitif, afektif maupun psikomotorik. Bila proses pembelajaran dapat dilaksanakan dengan memperhatikan adanya keseimbangan dari ketiga aspek tersebut, maka output pendidikan akan mampu menghasilkan lulusan yang kreatif. Nasution (1989) menyebutkan sejauh ini output pendidikan belum mampu menghasilkan lulusan yang dianggap menggunakan potensinya untuk terjun ke masyarakat secara nyata. Dengan demikian output pendidikan yang tidak kreatif tidak akan mampu menerjemahkan serta mengantisipasi kemajuan dan perkembangan masyarakat yang telah berjalan demikian cepat. Karena itu guru hendaklah berani mengajar secara dinamik, tematik dan kontekstual. Dalam pembelajaran CTL (Contextual Teaching Learning) peserta didik diberi kesempatan dan kebebasan untuk mengadakan pengamatan, pengklasifikasian, penafsiran, peramalan, penerapan, perencanaan, dan penelitian serta mengkomunikasikan hasil pembelajaran dalam kegiatan proses belajar mengajar. Dengan pembelajaran ini diharapkan kemampuan siswa dapat berkembang. Disamping itu dengan pembelajaran CTL akan menghasilkan cara belajar siswa aktif yang menimbulkan motivasi untuk mengembangkan diri. Guru aktif berperan sebagai fasilitator, motivator, dan mediator dalam proses belajar mengajar.

Depdiknas (2003: 10) menyebutkan Pembelajaran CTL memiliki tujuh asas. Asas ini sering juga disebut komponen CTL. Ketujuh asas itu adalah: konstruktivisme, inkuiri, bertanya, masyarakat belajar, pemodelan, refleksi, dan penilaian nyata. Pendekatan CTL merupakan konsep belajar yang membantu guru mengaitkan antara materi yang diajarkan dengan situasi dunia nyata siswa dan mendorong siswa membuat hubungan antara pengetahuan yang dimilikinya dengan penerapannya dalam kehidupan mereka sebagai anggota keluarga dan masyarakat. Dengan konsep itu, hasil pembelajaran diharapkan lebih bermakna bagi siswa. Proses pembelajaran berlangsung alamiah dalam bentuk kegiatan siswa bekerja dan mengalami, bukan mentransfer pengetahuan dari guru ke siswa. Strategi pembelajaran lebih dipentingkan daripada hasil. Dalam kelas yang memnggunakan pendekatan CTL tugas guru adalah membantu siswa mencapai tujuannya. Guru lebih banyak berurusan dengan strategi daripada memberi informasi. Tugas guru mengelola kelas sebagai sebuah tim yang bekerja bersama untuk menemukan sesuatu yang baru bagi anggota kelasnya (siswa).

\section{Hakikat Hasil Belajar Menulis Cerpen}

Belajar merupakan suatu proses perubahan tingkah laku. Belajar tidak terjadi secara alamiah tetapi hanya akan terjadi dengan adanya kondisi-kondisi (1) internal, yang antara lain menyangkut kesiapan siswa dan apa yang telah dipelajari sebelumnya, (2) eksternal, diantaranya berupa situasi belajar yang sengaja diatur oleh guru yang tujuannya untuk memperlancar proses belajar (Gagne, 1977).

Ausubel (1968) menyebutkan belajar berhubungan dengan bagaimana siswa memperoleh pengetahuan baru, yaitu penerimaan atau penemuan dan selanjutnya mengaitkan pengetahuan yang diperoleh pada struktur kognitif yang telah dimiliki. Suatu hal yang sifatnya karakteristik untuk teori ini adalah apa yang dinamakan dengan advance organizer yang apabila dipakai dapat meningkatkan kemampuan siswa untuk mempelajari informasi baru. Persyaratan dari belajar bermakna adalah (1) materi yang akan dipelajari harus bermakna secara potensial, dan (2) siswa yang akan belajar harus bertujuan untuk melaksanakan belajar bermakna, jadi memiliki kesiapan dan niat untuk belajar bermakna (meaningful learning).

Piaget (1967) mengemukakan bahwa pengetahuan tidak diperoleh secara pasif oleh seseorang, melainkan melalui tindakan. Menurutnya lagi bahwa belajar merupakan 
proses untuk membangun penghayatan terhadap suatu materi yang disampaikan, perkembangan kognitif anak bergantung pada seberapa jauh mereka aktif memanipulasi dan berinteraksi dengan lingkungannya. Perkembangan kognitif itu sendiri merupakan proses berkesinambungan tentang keadaan ketidakseimbangan dan keadaan keseimbangan.

Belajar merupakan perolehan proses perolehan pengetahuan dan perkembangan kognitif seseorang. Dimensi kesadaran soaial bersifat primer, sedangkan dimensi individualnya bersifat derivative atau turunan dan bersifat sekunder. Dalam proses belajar, disamping ditentukan oleh individu sendiri secara aktif juga dipengaruhi lingkungan sosial yang aktif pula (Vygotsky, 1978).

Menurut Bruner (1997) belajar yang terbaik merupakan proses berpikir, dan berpikir pada hakikatnya merupakan proses kignitif, sehingga manusia membedakan, memilih, dan menemukan objek, serta kemampuan untuk mengkonstruksi kembali informasi yang telah diterima.

Ruang lingkup pelajaran bahasa Indonesia terdiri dari komponen berbahasa dan bersastra yang meliputi standar kompetensi kemampuan mendengar, berbicara, membaca, dan menulis. Standar kompetensi tersebut dapat dibedakan lagi menjadi beberapa kompetensi dasar, misalnya menulis cerpen. Dengan standar kompetensi ini diharapkan: (1) siswa dapat mengembangkan potensinya sesuai dengan kemampuan, kebutuhan, dan minatnya, serta dapat menumbuhkan penghargaan terhadap hasil karya kesastraan dan hasil intelektual bangsa sendiri; (2) guru dapat memusatkan perhatian pada pengembangan dan kompetensi bahasa siswa dengan menyediakan berbagai kegiatan dan sumber belajar; (3) guru lebih mandiri dan leluasa dalam menentukan bahan ajar kebahasaan dan kesastraan sesuai dengan kondisi lingkungan sekolah dan kemampuan siswa; (4) orang tua dan masyarakat dapat secara aktif terlibat dalam pelaksanaan program kebahasaan dan kesastraan di sekolah; (5) sekolah dapat menyusun program pendidikan tentang kebahasaan dan kesastraan sesuai dengan keadaan siswa dan sumber belajar yang tersedia; (6) daerah dapat menentukan bahan dan sumber belajar kebahasaan dan kesastraan sesuai dengan kondidi kekhasan daerah dengan tetap dengan memperhatikan kepentingan nasional (Depdiknas,2006).
Menurut Muliono (1990: 968) menulis adalah melahirkan pikiran atau perasaan (seperti mengarang, membuat surat) dengan tulisan. Pikiran dan perasaan itu tentunya dibantu dengan alat komunikasi berupa bahasa. Selanjutnya dijelaskan pula bahasa merupakan sistem lambang bunyi berartikulasi (yang dihasilkan alat-alat ucap) yang bersifat sewenang-wenang dan konvensional yang dipakai sebaai alat komunikasi untuk melahirkan perasaan dan pikiran.

Tarigan (1994: 21) menjelaskan bahwa menulis merupakan kegiatan menurunkan atau melukiskan lambang-lambang grafik yang menggambarkan suatu bahasa yang dipahami oleh seseorang sehingga orang lain dapat membaca lambang-lambang grafik tersebut kalau mereka memahami bahasa dan lambing grafik tersebut. Lambing grafik yang ditulis merupakan representasi bahasa tertentu sehingga memiliki makna tertentu pula yang dapat dipahami oleh orang lain (pembaca).. Ketika menulis, penulis atau pengarang haruslah membedakan jenis tulisan yang akan dibuat. Bila jenis tulisan tersebut berupa karya ilmiah maka diksi atau pilihan kata haruslah menggunakan makna-makna kata yang denotative, yaitu pilihan kata yang bersifat lugas dan bermakna sebenranya. Sedangkan bila tulisan berbentuk karya sastra maka diksi atau pilihan kata yang dipakai boleh diperbanyak makna-makna kata konotatif, yaitu pilihan kata yang bersifat ungkapan atau kiasan.

Wiyanto (2005: 96) mengemukakan bahwa menulis cerpen harus banyak berkhayal karena cerpen memang karya fiksi yang berbentuk prosa. Peristiwa-peristiwa yang terjadi dalam cerpen hanya rekayasa pengarangnya. Demikian pula para pelaku yang terlibat dalam peristiwa itu. Waktu, tempat, dan suasana terjadi peristiwa pun hanya direka-reka oleh pengarangnya. Oleh karena itu, cerpen ( dan semua cerita fiksi) disebut cerita rekaan. Cerita dalam cerpen meskipun khayal, ceritanya masih masuk akal sehingga mungkin saja terjadi. Bahan baku cerpen memang berasal dari kisah yang benar-benar dialami sendiri oleh pengarangnya yang diolah sedemikian rupa dalam bentuk cerpen menjadi cerita fiksi, cerita khayal, atau cerita rekaan.

Rosa dalam Novakovich (1995) menyebutkan menulis cerita pendek fiksi merupakan hasil pemikiran yang di dalamnya terkandung emosi, imajinasi, dan ide-ide. Cerita berharga bukan sekedar cerita yang enak dan 
seru dibaca, melainkan cerita yang memperlihatkan kepaduan antara berbagai unsur yang ada di dalamnya, kemudian ada pencapaian estetika, dapat memberi pencerahan yang terus melekat di benak pembacanya.

Siswa dikatakan berhasil dalam pembelajaran menulis cerpen dilihat dari hasil belajarnya. Hasil pembelajaran harus memiliki efektivitas, efisiensi dan daya tarik (Reigeluth, 1983: 9). Efektivitas diukur dari tingkat pencapaian hasil belajar yang diperoleh oleh siswa, baik secara kualitas maupun kuantitas. Secara kualitas hasil belajar menunjukkan kebermaknaan isi bahan yang dipelajari dalam kehidupan sehari-hari, sedangkan kuantitas menunjukkan jumlah variasi hasil belajar yang dapat dicapai oleh siswa. Efisiensi diukur berdasarkan waktu yang dibutuhkan siswa untuk belajar, dalam arti semakin sedikit waktu yang dibutuhkan siswa untuk memahami isi materi pelajaran, maka semakin efisien hasil belajar yang diperoleh. Sedangkan daya tarik diukur dari ada tidaknya kecendrungan siswa termotivasi untuk belajar lebih lanjut dalam arti mengembangkan wawasan berdasarkan hasil belajar yang telah diperoleh.

Menurut Bloom dalam Anderson (2001) hasil belajar dibagi dalam tiga kawasan yaitu kognitif, afektif dan psikomotorik. Kemampuan pada ranah kognitif mencakup tujuan yang berhubungan dengan berpikir, mengetahui dan memecahkan masalah, yang meliputi pengetahuan, pemahaman, penerapan, analisis, sintesis dan evaluasi. Kemampuan pada ranah afektif mencakup tujuan-tujuan yang berkaitan dengan perhatian (minat), sikap, apresiasi, nilai dan sekumpulan emosi atau prasangka meliputi penerimaan dan pemeranan pengalaman. Kemampuan pada ranah psikomotorik mencakup keterampilan motorik, beberapa gerakan dari materi atau obyek beberapa perbuatan yang memerlukan koordinasi dari saraf-saraf otot, meliputi gerakan refleks, keterampilan gerakan dasar, keharmonisan, gerakan keterampilan kompleks.

Romizowski (1981) menyatakan hasil belajar diperoleh dalam bentuk pengetahuan dan keterampilan. Pengetahuan dikelompokkan dalam empat kategori, yaitu: (1) fakta, merupakan tentang objek nyata, asosiasi dari kenyataan, dan informasi verbal dari suatu objek, peristiwa atau manusia; (2) konsep, merupakan pengetahuan tentang seperangkat objek konkret atau definisi; (3) prosedur, merupakan pengetahuan tentang tindakan demi tindakan yang bersifat linier dalam mencapai suatu tujuan; (4) prinsip, merupakan pernyataan mengenai hubungan dari dua konsep atau lebih.

Cerpen tersusun atas unsur-unsur instrinsik dan unsur-unsur ekstrinsik. Dalam penelitian ini unsur yang dibahas hanya unsurunsur instrinsik saja. Unsur-unsur instrinsik sebagai pembangun cerita yang saling berkaitan erat antara satu dengan yang lainnya. Keterkaitan antara unsur-unsur pembangun cerita tersebut membentuk totalitas yang bersifat abstrak. Koherensi dan keterpaduan semua unsur cerita yang membentuk sebuah totalitas amat menentukan keindahan dan keberhasilan cerpen sebagai suatu bentuk cipta sastra. Kosasih (2004:251) menyebutkan bahwa unsur-unsur yang membangun cerpen dari dalam disebut unsur instriksik.Unsur-unsur instrinsik dalam cerpen terdiri atas: (1) tema, (2) amanat, (3) alur atau plot, (4) tokoh, (5) latar (setting), (6) sudut pandang (poin of view), dan (7) gaya bahasa.

Gaya bahasa yang digunakan oleh pengarang walaupun tidaklah terlalu luar biasa, adalah unik, karena selain dekat dengan watak dan jiwa penyair; juga membuat bahasa yang digunakan berbeda dalam makna dan kemesraanya. Jadi, gaya lebih merupakan pembawaan pribadi. Dengan gaya gaya tertentu pula pengarang dapat mengekalkan pengalaman rohaninya dan penglihatan bathinya, serta dengan itu pula ia menyentuh dan menggelitik hati pembacanya (Semi, 1988:49).

\section{Pembelajaran Contextual Teaching Learning (CTL)}

Pembelajaran CTL adalah suatu strategi pembelajaran yang menekankan kepada proses keterlibatan siswa secara penuh untuk dapat menemukan materi yang dipelajari dan menghubungkannya dengan situasi kehidupan nyata sehingga mendorong siswa untuk dapat menerapkannya dalam kehidupan mereka (Sanjaya, 2010: 255).

Dalam pembelajaran kontekstual siswa menemukan hubungan penuh makna antara ideide abstrak dengan penerapan praktis di dalam konteks dunia nyata. Siswa menginternalisasi konsep melalui penemuan, penguatan, keterhubungan. Pembelajaran kontekstual menghendaki kerja dalam sebuah tim, baik di kelas maupun di luar kelas. Pembelajaran kontekstual juga menuntut guru mendesain lingkungan belajar yang merupakan gabungan beberapa bentuk pengalaman untuk mencapai 
hasil yang diinginkan (Hull's and Sounders, 1996: 3).

Menurut Johnson (2002:25) sistem CTL adalah sebuah proses pendidikan yang bertujuan menolong para siswa melihat makna di dalam materi akademik yang mereka pelajari dengan cara menghubungkan subjek-subjek akademik dengan konteks dalam kehidupan keseharian mereka, yaitu dengan konteks keadaan pribadi, sosial, dan budaya mereka. Untuk mencapai tujuan ini, sistem tersebut meliputi delapan komponen yaitu: membuat keterkaitan-keterkaitan yang bermakna, melakukan pekerjaan yang berarti, melakukan pembelajaran yang diatur sendiri, melakukan kerja sama, berpikir kritis dan kreatif, membantu individu untuk tumbuh dan berkembang, mencapai standar yang tinggi, dan menggunakan penilaian autentik.

Melalui pembelajaran CTL, diharapkan hasil pembelajaran lebih bermakna bagi siswa. Siswa terlibat secara penuh dalam proses pembelajaran. Belajar dalam konteks CTL tidak hanya sekedar mendengarkan dan mencatat, tetapi belajar adalah proses berpengalaman secara langsung. Belajar melalui CTL diharapkan siswa dapat menemukan sendiri materi yang deipelajarinya. Lebih lanjut (Sanjaya, 2010: 255) menyatakan dalam pembelajaran CTL ada tiga hal yang harus dipahami: (1) CTL menekankan kepada proses keterlibatan siswa untuk menemukan materi, artinya proses belajar diorientasukan pada proses pengalaman secara langsung. Proses belajar dalam konteks CTL tidak mengharapkan agar siswa hanya menerima pelajaran akan tetapi proses mencari dan menemukan sendiri materi pelajaran; (2) CTL mendorong agar siswa menemukan hubungan antara materi yang dipelajari dengan situasi kehidupan nyata, artinya siswa dituntut untuk dapat menangkap hubungan antara pengalaman belajar di sekolah dengan kehidupan nyata. Hal ini sangat penting sebab dengan dapat mengkorelasikan materi yang ditemukan dengan kehidupan nyata, bukan saja bagi siswa materi itu akan bermakna secara fungsional, akan tetapi materi yang dipelajarinya akan tertanam erat dalam memori siswa, sehingga tidak akan mudah dilupakan; (3) CTL mendorong siswa untuk dapat menerapkannya dalam kehidupan, artinya CTL bukan hanya mengharapkan siswa dapat memahami materi yang dipelajarinya, akan tetapi bagaimana materi pelajaran itu dapat mewarnai perilakunya dalam kehidupan sehari- hari. Materi pelajaran dalam konteks CTL bukan untuk ditumpuk di otak dan kemudian dilupakan, akan tetapi sebagai bekal mereka dalam mengarungi kehidupan nyata.

$$
\text { Johnson (2002: }
$$

mengidentifikasikan ada delapan karakteristik pembelajaran kontekstual, yaitu: (1) membuat keterkaitan-keterkaitan yang bermakna (making meaningful connection). Siswa dapat mengatur diri sendiri sebagai orang yang belajar aktif dalam mengembangkan minatnya secara individual, orang yang dapat bekerja sendiri atau bekerja dalam kelompok, dan orang yang dapat bekerja sambil berbuat; (2) melakukan pekerjaan yang berarti (doing significant work). Siswa membuat hubungan-hubungan antara sekolah dan berbagai konteks yang ada dalam kehidupan nyata sebagai anggota masyarakat; (3) melakukan pembelajaran yang diatur sendiri (self-regulated learning). Siswa melakukan pekerjaan yang signifikan: ada tujuannya, ada urusannya dengan orang lain, ada hubungannya dengan dengan penentuan pilihan, dan ada produk/ hasilnya yang sifatnya nyata; (4) bekerja sama (collaborating). Siswa dapat bekerja sama sementara itu guru membantu siswa bekerja secara efektif dalam kelompok, membantu mereka memahami bagaimana mereka saling mempengaruhi dan saling berkomunikasi; (5) berpikir kritis dan kreatif (critical and creative thingking). Siswa dapat menggunakan tingkat berpikir yang lebih tinggi secara kritis dan kreatif: dapat menganalisis, membuat sintesis, memecahkan masalah, membuat keputusan, dan menggunakan buktibukti dan logika; (6) membantu individu untuk tumbuh dan berkembang (nurturing the individual). Siswa menumbuhkan pribadinya : mengetahui, memberi perhatian, memberi harapan-harapan yang tinggi, memotivasi dan memperkuat diri sendiri. Siswa tidak dapat berhasil tanpa dukungan orang dewasa; (7) mencapai standar tinggi (reaching high standards). Mengidentifikasi tujuan yang jelas dan memotivasi siswa untuk mencapainya. Menunjukkan kepada mereka cara untuk mencapai keberhasilan; (8) penggunaan penilaian sebenarnya (using authentic assessment). Penilaian autentik mengajak para siswa untuk menggunakan pengetahuan akademik dalam konteks dunia nyata untuk tujuan yang bermakna.

Dalam Pembelajaran Kontekstual (CTL) ada tujuh komponen yang melandasi pelaksanan proses pembelajaran. Seringkali 
komponen ini disebut juga dengan istilah asasasas pembelajaran Kontekstual (CTL). Depdiknas (2003: 10) menyebutkan tujuh komponen pembelajaran Kontekstual itu meliputi: (1) Kontruktivisme (contructivism) adalah landasan berpikir kontekstual yang menyatakan bahwa pengetahuan dibangun oleh manusia sedikit demi sedikit, yang hasilnya diperluas melaui konteks yang terbatas dan tidak datang tiba-tiba. Pengetahuan bukanlah seperangkat fakta-fakta, konsep atau kaidah yang siap untuk diambil dan diingat. Manusia harus mengkonstruksi pengetahuan itu dan member makna melalui pengalaman nyata. Siswa perlu dibiasakan untuk memecahkan masalah, menemukan sesuatu yang berguna bagi dirinya, dan bergelut dengan ide-ide; (2) Menemukan (inquiry). Merupakan Pengetahuan dan Keterampilan yang diperoleh siswa diharapkan bukan hasil mengingat seperangkat fakta-fakta, tetapi hasil dari menemukan sendiri. Guru harus selalu merancang kegiatan yang merujuk pada kegiatan menemukan, apa pun materi yang diajarkan; (3) Bertanya (questioning). Pengetahuan yang dimiliki seeorang selalu bermula dari bertanya. Bagi guru bertanya dipandang sebagai kegiatan untuk mendorong, membimbing dan menilai kemampuan berpikir siswa. Bagi siswa bertanya merupakan bagian penting dalam melakukan inquiri, yaitu menggali informasi, menginformasikan apa yang sudah diketahui, dan mengarahkan perhatian pada aspek yang belum diketahuinya; (4) Masyarakat belajar. (learning community). Hasil pembelajaran diperoleh dari kerjasama dengan orang lain. Hasil belajar yang diperoleh dari sharing antarteman, kelompok, dan antara yang tahu ke yang belum tahu; (5) Pemodelan. (modeling). Dalam pembelajaran keterampilan atau pengetahuan tertentu ada model yang bisa ditiru. guru dapat menjadi model, misalnya memberi contoh cara mengerjakan sesuatu.tetapi guru bukan satu-satunya model, artinya model dapat dirancang dengan melibatkan siswa, misalnya siswa ditunjuk untuk memberi contoh pada temannya, atau mendatangkan seseorang di luar sekolah, misalnya mendatangkan veteran kemerdekaan ke kelas; (6) Refleksi (reflection). Berpikir tentang apa yang baru dipelajari atau berpikir ke belakang tentang apa-apa yang sudah dilakukan di masa lalu. Siswa mengendapkan apa yang baru dipelajarinya sebagai struktur pengetahuan yang baru yang merupakan pengayaan atau revisi dari pengetahuan sebelumnya, refleksi merupakan respon terhadap kejadian, aktivitas, atau pengetahuan yang baru diterima; (7) Penilaian yang sebenarnya (authentic assessment). Kemajuan belajar dilihat dari proses, bukan semata hasil, dan dengan berbagai cara. Penilaian dapat berupa penilaian tertulis (pencil and paper test) dan penilaian berdasarkan perbuatan (performance based assessment), penugasan (project), produk (product), atau portofolio (portfolio).

Pembelajaran CTL mendasarkan pada filosofi konstruktivisme. Konstruktivisme adalah salah satu filsafat pengetahuan yang menekankan bahwa pengetahuan itu adalah konstruksi (bentukan) kita sendiri (Glasersfeld dalam Komalasari, 2010:15). Disebutkan pula oleh Glaserfeld dalam proses konstruksi itu diperlukan beberapa kemampuan sebagai berikut: (1) kemampuan mengingat dan mengungkapkan kembali pengalaman; (2) kemampuan membandingkan, mengambil keputusan (justifikasi) mengenai persamaan dan perbedaan; dan (3) kemampuan untuk lebih menyukai pengalaman yang satu daripada yang lain.

Pembelajaran CTL didukung oleh beberapa teori belajar yaitu: teori perkembangan dari Piaget, teori Free Discovery Learning dari Bruner, teori Meaningful Learning dari Ausebel, dan teori Belajar Vygotsky. Menurut Piaget (1967) bagaimana seseorang memperoleh kecakapan intelektual, pada umumnya akan berhubungan dengan proses mencari keseimbangan antara apa yang ia rasakan dan ketahui pada satu sisi dengan apa yang ia lihat sebagai suatu fenomena baru sebagai pengalaman dan persoalan. Bila seseorang dalam kondisi sekarang dapat mengatasi situasi baru, keseimbangan dirinya tidak akan terganggu, jika tidak, ia harus melakukan adaptasi dengan lingkungannya. Proses adaptasi ini melalui asimilasi, akomodasi, dan ekuilibrasi.

Dalam teori Free Discovery Learning Bruner (1977) menekankan ada nya pengaruh kebudayaan terhadap tingkah laku seseorang. Proses belajar akan belajar dengan baik dan kreatif jika guru memberikan kesempatan kepada siswa untuk menemukan suatu konsep, teori, aturan, atau pemahaman melalui contohcontoh yang ia jumpai dalam kehidupannya.

Dalam teori meaningful learning Ausebel (1968) menyebutkan belajar 
merupakan asimilasi bermakna. Materi yang dipelajari diasimilasikan dan dihubungkan dengan pengetahuan yang telah dimiliki sebelumnya. Faktor motivasi dan pengalaman emosional sangat penting dalam peristiwa belajar, sebab tanpa motivasi dan keinginan yang kuat dari pihak si pembelajar maka tidak akan terjadi asimilasi pengetahuan baru ke dalam struktur kognitif yang dimilikinya.

Belajar lebih bermakna bagi siswa jika materi pelajaran diurutkan dari umum ke khusus, dari keseluruhan ke rinci yang sering disebut sebagai subsumptive sequence. Selain itu, pembelajaran dirancang dengan advance organizers sebagai kerangka dalam bentuk abstrak atau ringkasan konsep-konsep dasar tentang apa yang dipelajari dan hubungannya dengan materi yang telah ada dalam struktur kognitif siswa. Vygotsky (1978) menjelaskan jalan pikiran seseorang harus dimengerti dari latar sosial budaya dan sejarahnya, perolehan pengetahuan dan perkembangan kognitif seseorang sesuai dengan teori sosiogenesis. Dimensi kesadaran sosial bersifat primer, sedangkan dimensi individualnya bersifat derivative atau merupakan turunan dan bersifat sekunder. Artinya pengetahuan dan perkembangan kognitif individu berasala dari sumber-sumber sosial di luar dirinya. Hal ini tidak berarti bahwa individu bersikap pasif dalam perkembangan kognitifnya, tetapi Vygotsky juga menekankan pentingnya peran aktif seseorang dalam mengonstruksi pengetahuannya.

Masalah yang diteliti dalam penelitian ini dirumuskan sebagai berikut: (1) Apakah pembelajaran CTL dapat meningkatkan hasil belajar menulis cerpen siswa?; dan (2) Apakah aktivitas siswa kelas XI IPS-2 SMA Negeri 1 Perbaungan meningkat dengan penerapan pembelajaran CTL?

\section{METODE}

Penelitian akan dilaksanakan di kelas XI IPS SMA Negeri 1 Perbaungan. Terdapat 3 kelas Reguler yaitu XI IPS-1, XI IPS-2, dan XI IPS-3. Siswa-siswa yang berada pada ketiga kelas tersebut memiliki hasil belajar menulis cerpen rendah. Untuk meningkatkan hasil belajar menulis cerpen, maka dilakukanlah penelitian tindakan kelas dengan penerapan pembelajaran CTL. Dari ketiga kelas tersebut diambil satu kelas terdiri dari 40 orang siswa yang terdiri dari 13 orang laki-laki dan 27 orang perempuan.
Tindakan Penelitian dilakukan dua siklus, setiap siklus terdiri dari empat tahap yaitu: perencanaan, tindakan, pengamatan, dan refleksi. Setiap siklus dilakukan dengan tiga kali pertemuan. Pada akhir tindakan siswa diberi tugas. Pada akhir siklus siswa diberi tes hasi belajar. Proses penelitian dapat diuraikan menjadi:

1. Perencanaan

Perencanaan tindakan merupakan kegiatan yang berisikan apa, mengapa, kapan, di mana, oleh siapa dan bagaimana tindakan itu dilakukan. Perencanaan tindakan pada siklus pertama harus berdasarkan pada identifikasi masalah yang dilakukan pada tahap pra penelitian tindakan kelas. Langkah-langkah dalam tahap perencanaan tindakan adalah adalah:

1) Menetapkan standar kompetensi dan kompetensi dasar yang menjadi tujuan pembelajaran.

2) Menentukan indikator-indikator pembelajaran dan dikembangkan dalam Rancangan Rencana Pembelajaran (RPP).

3) Merencanakan skenario pembelajaran yang berisikan langkah-langkah pembelajaran CTL disamping merencanakan bentukbentuk kegiatan yang akan dilakukan siswa.

4) Mempersiapkan bahan ajar dan media pembelajaran.

5) Mempersiapkan instrument observasi

2. Tindakan

Tindakan penelitian pada siklus pertama ini merupakan pelaksanaan dari semua rencana tindakan yang telah dibuat. Langkahlangkah yang dilakukan guru tentu saja mengacu kepada kurikulum yang berlaku.

1) Melaksanakan scenario pembelajaran yang direncanakan.

2) Mengelompokkan siswa, mempersiapkan kegiatan siswa yang telah sedikit banyak memahami materi ajar (menulis cerpen) di rumah sesuai konsep pembelajaran CTL. Siswa membawa sebuah cerpen per kelompok dari rumah.

3) Guru menyampaikan materi pembelajaran ( menulis cerpen) yang melibatkan aktivitas siswa. Dalam kegiatan ini guru menggunakan pendekatan pembelajaran CTL.

4) Pemberian tugas kelompok untuk menganalisis dan menemukan unsur-unsur instrinsik cerpen yang dibahas setiap kelompok dan member tugas individu 
berupa menulis cerpen. Guru mengadakan evaluasi pada setiap akhir siklus.

3. Pengamatan

Kegiatan pengamatan / observasi dilakukan observer bersamaan dengan pelaksanaan tindakan. Data yang dikumpulkan pada tahap ini berupa hasil observasi tentang aktivitas siswa selama kegiatan pembelajaran berlangsung, aktivitas guru, catatan lapangan tentang hal-hal yang terjadi di kelas yang mempengaruhi kegiatan belajar siswa selama pembelajaran berlangsung dengan alat bantu instrument.

4. Refleksi

Refleksi dalam Penelitian Tindakan Kelas merupakan upaya untuk mengkaji apa yang telah terjadi, apa yang telah dihasilkan atau yang belum dituntaskan. Hasil refleksi digunakan untuk menetapkan langkah lebih lanjut dalam upaya mencapai tujuan penelitian. Pada tahap refleksi kegiatan yang dilakukan oleh peneliti dan observer adalah menganalisis hasil tes dan hasil observasi untuk mempelajari hal-hal yang telah berlangsung di dalamkelas dan selanjutnya menentukan aktivitas apa yang perlu dipertahankan dan merevisi aktivitas yang kurang tepat dilakukan. Refleksi merupakan tindakan akhir dari penelitian yang hasil analisisnya dijadikan dasar bagi pelaksanaan tindakan pada siklus selanjutnya.

\section{Teknik Pengumpulan Data}

Teknik pengumpulan data yang akan digunakan adalah sebagai berikut:

- Observasi, pengamatan terhadap aktivitas siswa dan guru/ peneliti dengan menggunakan instrument format observasi.

- Tes Hasil Belajar, khusus dilakukan untuk mengumpulkan data pada akhir tindakan siklus I dan siklus II yang bertujuan untuk mengukur hasil belajar siswa. Tes Hasil Belajar Siswa dilakukan dengan memenulis cerpen. Evaluasi hasil belajar menulis cerpen dengan memperhatikan kriteriakrteria (indikator) yang telah didesain. Kriteria sukses yang digunakan adalah apabila skor rata-rata subjek penelitian $\geq$ 65,00 dan subjek yang memperoleh nilai $\geq$ 65,00 adalah $85 \%$. Kisi-kisi Tes hasil belajar Menulis cerpen siklus I dan II dapat dilihat pada tabel 1 berikut:

Tabel 1. Kisi-kisi Tes Hasil Belajar Menulis Cerpen siklus I dan II

\begin{tabular}{lcl}
\multicolumn{1}{c}{ Aspek } & Skor & \multicolumn{1}{c}{ Kriteria } \\
\hline 1. Tema & 5 & Tema sangat sesuai dengan isi cerpen \\
& 4 & Tema sesuai dengan cerpen isi cerpen \\
& 3 & Tema cukup sesuai dengan isi cerpen \\
& 2 & Tema kurang sesuai dengan isi cerpen \\
2. Amanat & 1 & Tema tidak sesuai dengan isi cerpen \\
& 5 & Amanat sangat sesuai dengan isi cerpen \\
& 4 & Amanat sesuai dengan cerpen isi cerpen \\
& 3 & Amanat cukup sesuai dengan isi cerpen \\
& 2 & Amanat kurang sesuai dengan isi cerpen \\
3. Alur/Plot & 1 & Amanat tidak sesuai dengan isi cerpen \\
& 5 & Rangkaian peristiwa disusun sangat logis dan sistematis \\
& 4 & Rangkaian peristiwa disusun logis dan sistematis \\
& 3 & Rangkaian peristiwa disusun cukup logis dan sistematis \\
& 2 & Rangkaian peristiwa disusun kurang logis dan sistematis \\
& 1 & Rangkaian peristiwa disusun tidak logis dan sistematis \\
\hline 4. Tokoh & 5 & Penggambaran karakter tokoh sangat jelas \\
& 4 & Penggambaran karakter tokoh jelas \\
& 3 & Penggambaran karakter tokoh cukup jelas \\
& 2 & Penggambaran karakter tokoh kurang jelas \\
& 1 & Penggambaran karakter tokoh tidak jelas \\
\hline 5. Lattar/setting & 5 & Pemilihan tempat, waktu, dan suasana yang menggambarkan \\
& 4 & terjadinya peristiwa sangat tepat \\
& & Pemilihan tempat, waktu, dan suasana yang menggambarkan \\
& 3 & terjadinya peristiwa tepat \\
& & Pemilihan tempat, waktu, dan suasana yang menggambarkan
\end{tabular}




\begin{tabular}{lll}
\hline & 2 & $\begin{array}{l}\text { terjadinya peristiwa cukup tepat } \\
\text { Pemilihan tempat, waktu, dan suasana yang menggambarkan } \\
\text { terjadinya peristiwa kurang tepat } \\
\text { Pemilihan tempat, waktu, dan suasana yang menggambarkan } \\
\text { terjadinya peristiwa tidak tepat }\end{array}$ \\
\hline 6. Sudut & 5 & $\begin{array}{l}\text { Sudut pandang yang digunakan sangat tepat menjelaskan tokoh } \\
\text { Pandang }\end{array}$ \\
Pengarang & 3 & Sudut pandang yang digunakan tepat menjelaskan tokoh \\
& 2 & Sudut pandang yang digunakan cukup tepat menjelaskan tokoh \\
& 1 & Sudut pandang yang digunakan kurang tepat menjelaskan tokoh \\
\hline 7. Gaya Bahasa & 5 & Penggunaan gaya bahasa sangat sesuai dengan situasi \\
& 4 & Penggunaan gaya bahasa sesuai dengan situasi \\
& 3 & Penggunaan gaya bahasa cukup sesuai dengan situasi \\
& 2 & Penggunaan gaya bahasa kurang sesuai dengan situasi \\
& 1 & Penggunaan gaya bahasa tidak sesuai dengan situasi \\
\hline
\end{tabular}

\section{Analisis Data}

Analisis terhadap seluruh temuan dalam proses pengembangan kegiatan pembelajaran dilakukan sesuai dengan masalah penelitian. Untuk data-data kualitatif dianalisis sesuai dengan analisis data kualitatif pada penelitian tindakan kelas. Analisis data kualitatif meliputi reduksi data, penyajian data, dan penarikan kesimpulan (Miles dan Huberman, 1992).

Reduksi data dilakukan dengan cara memilih data yang relevan, penting dan bermakna mulai dari awal pengumpulan data hingga penyusunan laporan penelitian. hasil catatan lapangan, hasil observasi, masih belum dapat memberikan informasi yang jelas. Untuk memperoleh informasi yang jelas dari data tersebut, dilakukanlah reduksi data. Reduksi data berguna untuk memilih dan menyederhanakan data tersebut, agar diperoleh informasi yang jelas.

Analisis data kuantitatif dilakukan terhadap data hasil belajar siswa, kemudian dibandingkan dengan indikator keberhasilan yang telah ditetapkan untuk melihat ketercapaian tujuan.

\section{HASIL PENELITIAN}

Siklus I

Analisis data hasil observasi menggunakan analisis prosentase. Skor yang diperoleh masing-masing indicator dijumlahkan dan hasilnya disebut jumlah skor. Selanjutnya dihitung persentase nilai rata-rata dengan cara membagi jumlah skor dengan skor yang dikalikan $100 \%$.

\section{Persentase Nilai Rata-Rata $(\mathrm{NR})=$ $\frac{\text { Jumlah Skor }}{\text { Skor Maksimal }} \times 100 \%$}

Kriteria taraf keberhasilan tindakan ditentukan sebabagai berikut:

$$
\begin{aligned}
& 85 \% \leq \mathrm{NR} \leq 100 \% \\
& 75 \% \leq \mathrm{NR}<85 \% \text { : }: \text { Sangat Baik } \\
& 65 \% \leq \mathrm{NR}<75 \% \text { : Cukup } \\
& 50 \% \leq \mathrm{NR}<65 \% \text { : Kurang } \\
& 0 \% \leq \mathrm{NR}<50 \%: \text { : Sangat Kurang } \\
& \text { Data hasil observasi }
\end{aligned}
$$

dalam kegiatan kelompok pada setiap

\begin{tabular}{|c|c|c|c|c|c|c|c|c|c|c|c|}
\hline \multirow[t]{2}{*}{ No } & \multirow[t]{2}{*}{ ASPEK YANG DIAMATI } & \multicolumn{8}{|c|}{ KELOMPOK } & \multirow{2}{*}{$\begin{array}{l}\text { Jum } \\
\text { lah }\end{array}$} & \multirow{2}{*}{$\begin{array}{c}\text { Persenta } \\
\text { se per } \\
\text { aspek }\end{array}$} \\
\hline & & 1 & 2 & 3 & 4 & 5 & 6 & 7 & 8 & & \\
\hline 1 & Terlibat aktif & 4 & 28 & 5 & 3 & 5 & 3 & 3 & 3 & 28 & 70 \\
\hline 2 & Bertanya / menjawab & 2 & 22 & 3 & 3 & 3 & 3 & 3 & 3 & 22 & 55 \\
\hline 3 & $\begin{array}{l}\text { Menanggapi } \\
\text { pertanyaan/jawaban }\end{array}$ & 3 & 22 & 2 & 3 & 4 & 3 & 3 & 2 & 22 & 55 \\
\hline 4 & Mengajukan Pendapat/ Saran & 2 & 18 & 3 & 2 & 2 & 3 & 2 & 2 & 18 & 45 \\
\hline & Jumlah & 11 & 90 & 13 & 11 & 14 & 12 & 11 & 10 & 90 & \\
\hline & Persentase per kelompok & 55 & 40 & 65 & 55 & 70 & 60 & 55 & 50 & 450 & \\
\hline
\end{tabular}
pertemuan dalam siklus I terdapat pada lampiran. Berikut ini rangkuman hasil aktivitas siswa dalam kelompok dapat dilihat pada tabel 2 berikut ini:

Tabel 2. Aktivitas Siswa Dalam Kelompok pada Pertemuan 1 Siklus I 
Data di atas menunjukkan bahwa pada pertemuan pertama siklus I, aktivitas siswa terlibat aktif $70 \%$, bertanya/menjawab 55\%, menanggapi pertanyaan/jawaban, 55\% dan mengajukan pendapat/saran $45 \%$.

Tabel 3. Aktivitas Siswa Dalam Kelompok pada Pertemuan 2 Siklus I

\begin{tabular}{|c|c|c|c|c|c|c|c|c|c|c|c|}
\hline \multirow[t]{2}{*}{ No } & \multirow{2}{*}{ ASPEK YANG DIAMATI } & \multicolumn{8}{|c|}{ KELOMPOK } & \multirow{2}{*}{$\begin{array}{c}\text { Jum } \\
\text { lah }\end{array}$} & \multirow{2}{*}{$\begin{array}{c}\text { Persenta } \\
\text { se per } \\
\text { aspek }\end{array}$} \\
\hline & & 1 & 2 & 3 & 4 & 5 & 6 & 7 & 8 & & \\
\hline 1 & Terlibat aktif & 3 & 5 & 4 & 4 & 4 & 3 & 3 & 4 & 30 & 70 \\
\hline 2 & Bertanya / menjawab & 3 & 3 & 3 & 3 & 3 & 3 & 3 & 3 & 24 & 60 \\
\hline 3 & $\begin{array}{l}\text { Menanggapi } \\
\text { pertanyaan/jawaban }\end{array}$ & 2 & 3 & 3 & 3 & 3 & 3 & 3 & 4 & 24 & 60 \\
\hline 4 & Mengajukan Pendapat/ Saran & 2 & 3 & 3 & 3 & 3 & 4 & 3 & 4 & 25 & 62.5 \\
\hline & Jumlah & 10 & 14 & 13 & 13 & 13 & 13 & 12 & 15 & 103 & \\
\hline & Persentase per kelompok & 50 & 70 & 65 & 65 & 65 & 65 & 60 & 75 & 515 & \\
\hline
\end{tabular}

Sedangkan aktivitas siswa pada pertemuan kedua siklus I adalah siswa terlibat aktif $75 \%$, bertanya/menjawab $60 \%$, menanggapi pertanyaan/jawaban, $60 \%$ dan mengajukan pendapat/saran $62.5 \%$.

Tabel 4. Aktivitas Siswa Dalam Kelompok pada Pertemuan 3 Siklus I

\begin{tabular}{|c|c|c|c|c|c|c|c|c|c|c|c|}
\hline \multirow[t]{2}{*}{ No } & \multirow[t]{2}{*}{ ASPEK YANG DIAMATI } & \multicolumn{8}{|c|}{ KELOMPOK } & \multirow{2}{*}{$\begin{array}{l}\text { Jum } \\
\text { lah }\end{array}$} & \multirow{2}{*}{$\begin{array}{c}\text { Persenta } \\
\text { se per } \\
\text { aspek }\end{array}$} \\
\hline & & 1 & 2 & 3 & 4 & 5 & 6 & 7 & 8 & & \\
\hline 1 & Terlibat aktif & 5 & 5 & 5 & 5 & 5 & 5 & 5 & 5 & 40 & 100 \\
\hline 2 & Bertanya / menjawab & 2 & 4 & 4 & 3 & 5 & 5 & 4 & 4 & 31 & 77.5 \\
\hline 3 & $\begin{array}{l}\text { Menanggapi } \\
\text { pertanyaan/jawaban }\end{array}$ & 4 & 5 & 5 & 4 & 3 & 4 & 3 & 4 & 32 & 80 \\
\hline 4 & Mengajukan Pendapat/ Saran & 3 & 4 & 4 & 5 & 4 & 4 & 4 & 3 & 31 & 77.5 \\
\hline & Jumlah & 14 & 18 & 18 & 17 & 17 & 18 & 16 & 16 & 134 & \\
\hline & Persentase per kelompok & 70 & 90 & 90 & 85 & 85 & 90 & 80 & 80 & 670 & \\
\hline
\end{tabular}

Pertemuan ketiga siklus I sampai pertemuan kedua meningkat $5 \%$, pada menunjukkan siswa terlibat aktif $100 \%$, pertemuan kedua sampai pertemuan ketiga bertanya/menjawab $77.5 \%$, menanggapi siklus $\mathrm{I}$ ini adalah $17.5 \%$. Persentase pertanyaan/jawaban, $80 \%$ dan mengajukan peningkatan aktivitas siswa menanggapi pendapat/saran $77.5 \%$. Dari tabel di atas pertanyaan/jawaban pada siklus I adalah tampak adanya peningkatan aktivitas kelompok sebagai berikut: pada pertemuan pertama dari pertemuan pertama sampai dengan sampai pertemuan kedua meningkat $5 \%$, pada pertemuan ketiga pada siklus I.

Pada setiap pertemuan, aktifitas siswa dalam kelompok semakin meningkat. Peningkatan itu adalah sebagai berikut: siswa terlibat aktif dari pertemuan pertama ke pertemuan kedua meningkat $5 \%$, dari pertemuan kedua sampai pertemuan ketiga siklus I ini adalah $25 \%$. Persentase peningkatan aktivitas siswa bertanya/menjawab pada siklus I adalah sebagai berikut: pada pertemuan pertama pertemuan kedua sampai pertemuan ketiga siklus I ini adalah $20 \%$. Dan Persentase peningkatan aktivitas siswa mengajukan pendapat/saran pada siklus I adalah sebagai berikut: pada pertemuan pertama sampai pertemuan kedua meningkat $17.5 \%$, pada pertemuan kedua sampai pertemuan ketiga siklus I ini adalah $15 \%$.

Hasil observasi aktivitas guru/peneliti dapat dilihat pada table 4 berikut: 
Tabel 5. Tabel Aktivitas Guru dalam Pembelajaran

\begin{tabular}{|c|c|c|}
\hline No & ASPEK YANG DIAMATI & SKOR \\
\hline \multirow[t]{5}{*}{$\mathrm{I}$} & PENDAHULUAN & \\
\hline & 1. Mempersiapkan siswa untuk belajar & 5 \\
\hline & $\begin{array}{l}\text { 2. Melakukan kegiatan apersepsi ( memgadakan tanya jawab berkaitan dengan } \\
\text { materi pelajaran yang akan dibahas untuk melihat sejauh mana pengetahuan } \\
\text { siswa) }\end{array}$ & 5 \\
\hline & 3. Menyampaikan tujuan pembelajaran & 4 \\
\hline & $\begin{array}{l}\text { 4. Menyampaikan manfaat materi pelajaran yang dibahas dalam kehidupan } \\
\text { sehari-hari }\end{array}$ & 2 \\
\hline \multirow[t]{2}{*}{ II } & INTI PEMBELAJARAN & \\
\hline & 5 Menguasai materi pelajaran & 5 \\
\hline \multirow{11}{*}{ No } & ASPEK YANG DIAMATI & SKOR \\
\hline & 6. Mengaitkan materi dengan pengetahuan yang relevan & \\
\hline & $\begin{array}{l}\text { 7. Melaksanakan pembelajaran sesuai dengan kompetensi ( tujuan ) yang akan } \\
\text { dicapai }\end{array}$ & 4 \\
\hline & 8. Membentuk kelompok & 5 \\
\hline & 9. Mengadakan diskusi kelompok & 5 \\
\hline & $\begin{array}{l}\text { 10. Memberi kesempatan kepada siswa untuk mengadakan tanya jawab } \\
\text { antarkelompok }\end{array}$ & 5 \\
\hline & 11. Menggunakan media pembelajaran & 2 \\
\hline & 12. Melaksanakan pembelajaran sesuai dengan alokasi waktu & 2 \\
\hline & 13. Memantau kemajuan belajar selama proses & 3 \\
\hline & 14. Pemodelan & 4 \\
\hline & 15. Meminta siswa menemukan /memahami materi berikutnya di rumah & 5 \\
\hline \multirow[t]{5}{*}{ III } & Penutup & \\
\hline & 16. Melakukan refleksi atau membuat rangkuman dengan melibatkan siswa & 5 \\
\hline & $\begin{array}{l}\text { 17. Melaksanakan tindak lanjut dengan memberikan arahan, atau kegiatan, atau } \\
\text { tugas sebagai bagian remidi/ pengayaan }\end{array}$ & 5 \\
\hline & Skor Total & 67 \\
\hline & Skor Akhir $=($ Skor total $) / 85 \times 100$ & 78.82 \\
\hline
\end{tabular}

Tabel di atas menunjukkan aktivitas peneliti/guru dari tahap pedahuluan pembelajaran, tahap inti dan tahap penutup sudah menunjuukan semua indikator memperoleh nlai tinggi yaitu antara 4 dan 5 . Hal ini menunjukkan bahwa indikator sudah baik, dengan demikian aktivitas guru/peneliti dalam pembelajaran mencapai keberhasilan $78,23 \%$.

\section{Siklus II}

Data hasil observasi aktivitas siswa dalam kegiatan kelompok pada setiap pertemuan dalam siklus I terdapat pada lampiran. Berikut ini rangkuman hasil aktivitas siswa dalam kelompok dapat dilihat pada tabel berikut ini:

$\begin{array}{cccc} & \text { Aktivitas siswa dapat dilihat pada } \\ \text { tabel } & 6 & \text { berikut }\end{array}$

Tabel 6. Aktivitas Siswa Dalam Kelompok pada Pertemuan 1 Siklus II

\begin{tabular}{|c|c|c|c|c|c|c|c|c|c|c|c|}
\hline \multirow[t]{2}{*}{ No } & \multirow[t]{2}{*}{ ASPEK YANG DIAMATI } & \multicolumn{8}{|c|}{ KELOMPOK } & \multirow{2}{*}{$\begin{array}{l}\text { Jum } \\
\text { lah }\end{array}$} & \multirow{2}{*}{$\begin{array}{c}\text { Persenta } \\
\text { se per } \\
\text { aspek }\end{array}$} \\
\hline & & 1 & 2 & 3 & 4 & 5 & 6 & 7 & 8 & & \\
\hline 1 & Terlibat aktif & 5 & 5 & 5 & 5 & 5 & 5 & 5 & 5 & 40 & 100 \\
\hline 2 & Bertanya / menjawab & 4 & 3 & 4 & 5 & 4 & 4 & 3 & 5 & 32 & 80 \\
\hline 3 & $\begin{array}{l}\text { Menanggapi } \\
\text { pertanyaan/jawaban }\end{array}$ & 4 & 4 & 5 & 3 & 5 & 5 & 4 & 3 & 33 & 82.5 \\
\hline 4 & Mengajukan Pendapat/ Saran & 4 & 4 & 4 & 3 & 4 & 4 & 4 & 4 & 31 & 77.5 \\
\hline & Jumlah & 17 & 16 & 18 & 16 & 18 & 18 & 16 & 17 & & \\
\hline & Persentase per kelompok & 85 & 80 & 90 & 80 & 90 & 90 & 80 & 85 & & \\
\hline
\end{tabular}


Data di atas menunjukkan bahwa pada pertemuan pertama siklus II, aktivitas siswa terlibat aktif $100 \%$, bertanya/menjawab $80 \%$, menanggapi pertanyaan/jawaban $82.5 \%$ dan mengajukan pendapat/saran $77.5 \%$.

Tabel 7. Aktivitas Siswa Dalam Kelompok pada Pertemuan 2 Siklus II

\begin{tabular}{|c|c|c|c|c|c|c|c|c|c|c|c|}
\hline \multirow[t]{2}{*}{ No } & \multirow{2}{*}{ ASPEK YANG DIAMATI } & \multicolumn{8}{|c|}{ KELOMPOK } & \multirow{2}{*}{$\begin{array}{l}\text { Jum } \\
\text { lah }\end{array}$} & \multirow{2}{*}{$\begin{array}{c}\text { Persenta } \\
\text { se per } \\
\text { aspek }\end{array}$} \\
\hline & & 1 & 2 & 3 & 4 & 5 & 6 & 7 & 8 & & \\
\hline 1 & Terlibat aktif & 5 & 5 & 5 & 5 & 5 & 5 & 5 & 5 & 40 & 100 \\
\hline 2 & Bertanya / menjawab & 5 & 4 & 4 & 4 & 5 & 5 & 4 & 4 & 35 & 87.5 \\
\hline 3 & $\begin{array}{l}\text { Menanggapi } \\
\text { pertanyaan/jawaban }\end{array}$ & 4 & 4 & 4 & 3 & 5 & 3 & 4 & 4 & 31 & 77.5 \\
\hline 4 & Mengajukan Pendapat/ Saran & 3 & 4 & 5 & 5 & 3 & 4 & 4 & 3 & 31 & 77.5 \\
\hline & Jumlah & 17 & 17 & 18 & 17 & 18 & 17 & 17 & 16 & 137 & \\
\hline & Persentase per kelompok & 85 & 85 & 90 & 85 & 90 & 85 & 85 & 80 & 685 & \\
\hline
\end{tabular}

Sedangkan aktivitas siswa pada pertemuan kedua siklus II adalah siswa terlibat aktif $100 \%$, bertanya/menjawab $87.5 \%$, menanggapi pertanyaan/jawaban $77.5 \%$ dan mengajukan pendapat/saran $77.5 \%$.

Tabel 8. Aktivitas Siswa dalam Kelompok pada Pertemuan 3 Siklus II

\begin{tabular}{|c|c|c|c|c|c|c|c|c|c|c|c|}
\hline \multirow[t]{2}{*}{ No } & \multirow[t]{2}{*}{ ASPEK YANG DIAMATI } & \multicolumn{8}{|c|}{ KELOMPOK } & \multirow{2}{*}{$\begin{array}{l}\text { Jum } \\
\text { lah }\end{array}$} & \multirow{2}{*}{$\begin{array}{l}\text { Persenta } \\
\text { se per } \\
\text { aspek }\end{array}$} \\
\hline & & 1 & 2 & 3 & 4 & 5 & 6 & 7 & 8 & & \\
\hline $\mathbf{1}$ & Terlibat aktif & 5 & 5 & 5 & 5 & 5 & 5 & 5 & 5 & 40 & 100 \\
\hline 2 & Bertanya / menjawab & 3 & 5 & 5 & 5 & 4 & 5 & 4 & 6 & 37 & 92.5 \\
\hline 3 & $\begin{array}{l}\text { Menanggapi } \\
\text { pertanyaan/jawaban }\end{array}$ & 5 & 4 & 4 & 5 & 4 & 4 & 5 & 4 & 35 & 87.5 \\
\hline 4 & Mengajukan Pendapat/ Saran & 5 & 4 & 5 & 5 & 4 & 5 & 4 & 5 & 37 & 92.5 \\
\hline & Jumlah & 18 & 18 & 19 & 20 & 17 & 19 & 18 & 20 & 149 & \\
\hline & Persentase per kelompok & 90 & 90 & 95 & 100 & 85 & 95 & 90 & 100 & 745 & \\
\hline
\end{tabular}

Pertemuan ketiga siklus II menunjukkan siswa terlibat aktif $100 \%$, bertanya/menjawab $92.5 \%$, menanggapi pertanyaan/jawaban, $87.5 \%$ dan mengajukan pendapat/saran $92.2 \%$. Dari tabel di atas tampak adanya peningkatan aktivitas siswa dalam kelompok dari pertemuan pertama sampai pertemuan ketiga siklus II.

Persentase peningkatan itu adalah sebagai berikut: siswa terlibat aktif dari pertemuan pertama ke pertemuan kedua tidak terdapat peningkatan karena sudah mencapai $100 \%$ ini berarti telah memenuhi kriteria yang diharapkan dengan predikat sangat baik. Persentase peningkatan aktivitas siswa bertanya/menjawab pada siklus II adalah sebagai berikut: pada pertemuan pertama sampai pertemuan kedua meningkat $7.5 \%$, pada pertemuan kedua sampai pertemuan ketiga siklus I ini adalah $5 \%$. Persentase peningkatan aktivitas siswa menanggapi pertanyaan/jawaban pada siklus I adalah sebagai berikut: pada pertemuan pertama sampai pertemuan kedua menurun $5 \%$, tetapi pada pertemuan kedua sampai pertemuan ketiga siklus I ini meningkat kembali sampai $10 \%$. Dan Persentase peningkatan aktivitas siswa mengajukan pendapat/saran pada siklus II adalah sebagai berikut: pada pertemuan pertama sampai pertemuan kedua tidak meningkat karena perolehan skor yang sama yaitu $77.5 \%$, akan tetapi pada pertemuan kedua sampai pertemuan ketiga siklus II ini meningkat sampai $15 \%$.

Hasil observasi aktivitas guru/peneliti dapat dilihat pada tabel 9 berikut: 
Tabel 9. Aktivitas Guru Dalam Pembelajaran

\begin{tabular}{|c|c|c|}
\hline No & ASPEK YANG DIAMATI & SKOR \\
\hline \multirow[t]{5}{*}{ I } & PENDAHULUAN & \\
\hline & 1. Mempersiapkan siswa untuk belajar & 5 \\
\hline & $\begin{array}{l}\text { 2. Melakukan kegiatan apersepsi ( memgadakan tanya jawab berkaitan dengan } \\
\text { materi pelajaran yang akan dibahas untuk melihat sejauh mana pengetahuan } \\
\text { siswa) }\end{array}$ & 5 \\
\hline & 3. Menyampaikan tujuan pembelajaran & 5 \\
\hline & $\begin{array}{l}\text { 4. Menyampaikan manfaat materi pelajaran yang dibahas dalam kehidupan } \\
\text { sehari-hari }\end{array}$ & 5 \\
\hline \multirow[t]{12}{*}{ II } & INTI PEMBELAJARAN & \\
\hline & 5 Menguasai materi pelajaran & 5 \\
\hline & 6. Mengaitkan materi dengan pengetahuan yang relevan & 4 \\
\hline & $\begin{array}{l}\text { 7. Melaksanakan pembelajaran sesuai dengan kompetensi ( tujuan ) yang akan } \\
\text { dicapai }\end{array}$ & 5 \\
\hline & 8. Membentuk kelompok & 5 \\
\hline & 9. Mengadakan diskusi kelompok & 5 \\
\hline & $\begin{array}{l}\text { 10. Memberi kesempatan kepada siswa untuk mengadakan tanya jawab } \\
\text { antarkelompok }\end{array}$ & 5 \\
\hline & 11. Menggunakan media pembelajaran & 5 \\
\hline & 12. Melaksanakan pembelajaran sesuai dengan alokasi waktu & 5 \\
\hline & 13. Memantau kemajuan belajar selama proses & 4 \\
\hline & 14. Pemodelan & 5 \\
\hline & 15. Meminta siswa menemukan /memahami materi berikutnya di rumah & 5 \\
\hline \multirow[t]{5}{*}{ III } & Penutup & \\
\hline & 16. Melakukan refleksi atau membuat rangkuman dengan melibatkan siswa & 5 \\
\hline & $\begin{array}{l}\text { 17. Melaksanakan tindak lanjut dengan memberikan arahan, atau kegiatan, atau } \\
\text { tugas sebagai bagian remidi/ pengayaan }\end{array}$ & 5 \\
\hline & Skor Total & 83 \\
\hline & Skor Akhir $=($ Skor total $) / 85 \times 100$ & 97.64 \\
\hline
\end{tabular}

Tabel di atas menunjukkan aktivitas peneliti/guru dari tahap pedahuluan pembelajaran, tahap inti dan tahap penutup sudah menunjukan semua indikator memperoleh nlai tinggi yaitu antara 4 dan 5 . Hal ini menunjukkan bahwa indikator sudah baik, dengan demikian aktivitas guru/peneliti dalam pembelajaran mencapai keberhasilan $97,64 \%$.

Setelah siklus II dilakukan hasil belajar menulis cerpen siswa menunjukkan peningkatan, aktivitas siswa dalam kelompok dan aktivitas guru juga mengalami peningkatan kea rah yang lebih baik, berikut ini akan dijelaskan persentase peningkatan tersebut:

1. Adanya peningkatan hasil belajar menulis cerpen siswa kelas XI IPS-2 SMA Negeri 1 Perbaungan dengan penerapan pembelajaran CTL yang dilakukan dalam dua siklus. Berdasarkan perolehan skor, dari siklus $1 \mathrm{ke}$ siklus 2 juga terjadi peningkatan rata-rata skor baik oleh penilai 1 maupun penilai 2 . Hasil penilai 1 menunjukkan rata-rata skor siklus 2 meningkat 5,92 terhadap rata-rata skor siklus 1 atau meningkat 27, $50 \%$. Sedangkan hasil penilai 2 menunjukkan ratarata skor siklus 2 meningkat 7,05 terhadap rata-rata skor siklus 1 atau meningkat 33,85 $\%$. pada siklus II hasil belajar menulis cerpen siswa sudah menunjukkan hasil yang memuaskan. skor rata-rata subjek penelitian pada penilai 1 adalah 78.42. Siswa yang memperoleh nilai $\geq 65,00$ sebanyak 38 orang atau sama dengan $95 \%$. Begitu pula halnya dengan penilai 2, skor rata-rata subjek penelitian adalah 79.65. Siswa yang memperoleh nilai $\geq 65,00$ atau sebanyak 39 orang atau sama dengan $97.5 \%$. Pembelajaran siklus II ini dikatakan telah berhasil karena telah memenuhi kriteria sukses sebagaimana yang disebutkan pada $\mathrm{Bab}$ III. Kriteria sukses yang digunakan adalah apabila nilai rata-rata subjek penelitian $\geq 65,00$ dan subjek yang memperoleh nilai $\geq 65,00$ adalah $85 \%$. 
2. Aktivitas siswa dalam kelompok ketika proses belajar mengajar (PBM) di kelas semakin membaik. Presentase kenaikan itu pada siklus I adalah $25 \%$ dan pada siklus II mencapai $100 \%$. Hal ini menunjukkan bahwa pada pertemuan-pertemuan siklus I siswa masih banyak yang belum terlibat aktif dalam kelompoknya, tetapi setelah dilanjutkan penerapan pembelajara CTL pada siklus II siswa tampaknya sudah dapat menumbuhkan rasa kebersamaan, dan saling menghargai kebersamaan tersebut dalam kelompok-kelompok belajar yang ada. Kegiatan bertanya dan menjawab juga meningkat, rasa sungkan/ malu untuk bertanya atau memberi jawaban ketika diskusi antarkelompok berlangsung semakin lama semakin berkurang. Hal ini tampak pada persentase peningkatan kegiatan bertanya dan menjawab yaitu pada siklus I $60 \%$ kemudian pada siklus II mencapai 92.5 $\%$. Begitu pula halnya dengan kegiatan menanggapi pertanyaan/jawaban dari teman, meningkat dari $80 \%$ pada siklus I menjadi $87.5 \%$ pda siklus II. Siswa juga sudah mulai mampu memberikan pendapat/saran berkaitan dengan topik/ materi pembelajaran yang sedang dibahas. Pada siklus I adalah $77.5 \%$ dan mencapai $92.5 \%$ pada siklus II.

3. Aktivitas peneliti/guru yang mengajar menggunakan pembelajaran CTL semakin membaik/ meningkat hal ini berdasarkan hasil pengamatan yang dilakukan observer baik dari tahap pedahuluan pembelajaran, tahap inti sampai tahap penutupan pada siklus I adalah 78,23\%. Kemudian meningkat pada siklus II mencapai 97,64\%.

Temuan dalam penelitian ini adalah:

Dalam proses belajar mengajar (PBM) pada siklus I hasil belajar menulis cerpen siswa masih rendah baik yang dinilai oleh penilai 1 maupun penilai 2, belum mencapai kriteria ketuntasan minimal (KKM).. Pada siklus II hasil belajar menulis cerpen siswa meningkat dibandingkan pada siklus I. Aktivitas guru dalam mengajar juga semakin meningkat pada siklus II.

Begitu pula dengan aktivitas siswa dalam kelompok belum menunjukkan kerja sama kelompok yang baik, masih ada siswa yang malu dan belum terbiasa dengan belajar berkelompok ini tampak pada pertemua pertama dan kedua siklus I, siswa masih bingung untuk berperan aktif dalam kegiata kelompok mereka hal ini karena kegiatan berdiskusi, Tanya jawab sesame teman jarang dilakukan sebelumnya. Setelah dilakukan pertemua ketiga pada siklus I siswa mulai terbiasa untuk berperan serta dalam kegiatan belajar kelompok. Pada siklus II aktivitas siswa dalam kelompok semakin menunjukkan peningkatan sampai pada pertemuan terakhir siklus II, siswa sudah terbiasa aktif dalam kelompok masing-masing, tidak merasa sungkan dan malu ketika mengadakan tanya jawab, menanggapi pertanyaan/jawaban dari teman bahkan mereka telah mampu mengajukan saran- saran bagi kelompok lain.

Pelaksanaan lembar kerja siswa pada materi pelajaran menulis cerpen yang seyogyanya dilakukan pada setiap akhir pertemuan tidak dapat dilaksanakan semaksimal mungkin. Hal ini disebabkan oleh waktu yang tersedia untuk kegiatan ini masih sangat sedikit, sehingga lembar kerja siswa dapat terlaksana pada akhir pertemua keempat dan pada akhir pertemuan keenam.

Demikian pula dengan kegiatan latihan menulis cerpen dalam kegiatan belajar mengajar (di kelas) juga tidak dapat dilakukan. Hal ini juga dikarenakan oleh keterbatsan waktu, sehingga pelatihan menulis cerpen dilakukan sebagai pelatihan menulis cerpen di rumah (kegiatan mandiri ).

\section{PEMBAHASAN}

Penerapan pembelajaran CTL dalam kegiatan PBM di kelas XI IPS-2 SMA Negeri 1 Perbaungan dapat meningkatkan hasil belajar menulis cerpen siswa. Konsep pembelajaran CTL membantu merubah kegiatan belajar yang monoton menjadi kegiatan belajar yang dapat mengaktifkan siswa baik untuk bekerja dalam kelompok maupun berlatih secara pribadi. Belajar dalam kelompok dapat menumbuhkan rasa kebersamaan dan menganggap semua anggotanya berharga serta dapat member wawasan baru yang dapat memperluas potensi diri. Johnson (2010:170) menjelaskan saat siswa dari berbagai latar belakang mendengarkan yang lain dengan sabar, membimbing mereka untuk mendapat wawasan yang baru yang dapat memperluas potensi diri mereka. Kesuksesan lebih mudah dicapai oleh para anggota kelompok yang bekerja sama daripada kesuksesan yang diraih seseorang yang berusaha sendiri.

Pembelajaran CTL membantu siswa mengaitkan antara materi yang diajarkan 
dengan situasi nyata dan mendorong siswa membentuk hubungan antara pengetahuan yang dimilikinya dengan penerapan dalam kehidupan. Sanjaya (2010: 254) menjelaskan siswa dituntut untuk dapat menangkap hubungan antara pengalaman belajar di sekolah dengan kehidupan nyata. Hal ini sangat penting, sebab debgan data mengorelasikan materi yang ditemukan dengan kehidupan nyata materi akan tertanam erat dalam memori siswa, sehingga tidak akan mudah dilupakan. Materi pelajaran dalam CTL bukan untuk disimpan bukan untuk dihapal saja melainkan sebagai bekal mereka dalam mengarungi kehidupan nyata. Pembelajaran CTL mendorong agar siswa dalam pelaksanaan strategi pembelajaran CTL kegiatan belajar diwujudkan dalam berbagai kegiatan yang menuntuk keterlibatan intelektual-emosional siswa dalam proses belajar melalui keaktifan siswa secara fisik dan nonfisik.

Kegiatan belajar mengajar dalam penelitian ini diwujudkan dalam pelaksanan strtegi pembelajaran CTL dengan didasari oleh prosedur dan proses penelitian tindakan kelas dengan dua siklus. Masing-masing siklus ada empat tahap yaitu : perencanaan, tindakan, pengamatan dan refleksi. Pada tahap perencanaan, peneliti menetapkan standar kompetensi dan kompetensi dasar yang menjadi tujuan pembelajaran, menentukan indikatorindikator pembelajaran dan dikembangkan dalam RPP, merencanakan skenario pembelajaran yang berisikan langkah-langkah pembelajaran CTL, mempersiapkan bahan ajar, dan Mempersiapkan instrument observasi.

Tindakan merupakan merupakan pelaksanaan dari semua rencana tindakan yang telah dibuat, baik dalam siklus I maupun pada siklus II. Langkah-langkah yang dilakukan guru berupa melaksanakan scenario pembelajaran yang direncanakan, mengelompokkan siswa, menyampaikan materi pembelajaran (menulis cerpen) yang melibatkan aktivitas siswa. Dalam kegiatan ini guru menggunakan pendekatan pembelajaran CTL, Pemberian tugas kelompok untuk menganalisis dan menemukan unsurunsur instrinsik cerpen yang dibahas setiap kelompok dan member tugas individu berupa menulis cerpen. Guru mengadakan evaluasi pada setiap akhir siklus.

Pada tahap observasi, baik itu siklus I maupun siklus II, observer dan peneliti mengamati secara lansung aktivitas siswa dan guru dalam kegiatan belajar mengajar dengan alat bantu instrument observasi. Tahap yang terakhir ialah refleksi, refleksi dilakukan pada siklus I dan siklus II. Refleksi merupakan upaya untuk mengkaji apa yang telah terjadi, apa yang telah dihasilkan atau yang belum dituntaskan. Hasil refleksi digunakan untuk menetapkan langkah lebih lanjut dalam upaya mencapai tujuan penelitian. Pada tahap refleksi kegiatan yang dilakukan oleh peneliti dan observer adalah menganalisis hasil tes dan hasil observasi untuk mempelajari hal-hal yang telah berlangsung di dalamkelas dan selanjutnya menentukan aktivitas apa yang perlu dipertahankan dan merevisi aktivitas yang kurang tepat dilakukan

Kegiatan belajar mengajar didasarkan pada komponen pembelajaran CTL, baik itu pada aktivitas guru maupun aktivitas yang dilakukan siswa. Kegiatan belajar di kelas dibagi dalam tiga tahap yaitu: pendahuluan, inti, dan penutup. Penjelasan ketiga tahp itu adalah sebagai berikut:

Pendahuluan, dalam tahap ini guru melakukan apersepsi dan motivasi kepada siswa, yakni kegiatan mengadakan tanya jawab berkaitan dengan materi yang akan diajarkan untuk melihat sejauh mana pengetahuan siswa dan menjelaskan tujuan pembelajaran serta mengaitkan materi pelajaran dengan kehidupan sehari-hari siswa. Bagi siswa dalam tahap pendahuluan ini, mereka bergabung dalam kelompok-kelompok belajar yang telah ditentukan sebelumnya. Bila dikaitkan dengan komponen CTL, kegiatan siswa berkaitan dengan kontruktivisme dan inkuri.

Inti, kegiatan siswa meliputi mendiskusikan hasil temuan mereka sesuai dengan kelompoknya masing-masing (komponen CTL: learning community, Qoestening dan inquiry), Siswa melaporkan hasil diskusi (komponen CTL: learning community dan inquiry), Siswa mengadakan tanya jawab antarkelompok (komponen CTL: learning community).

Penutup, bagi siswa, dengan bantuan guru siswa menyimpulkan hasil observasi sekitar masalah menulis cerpen sesuai dengan indikator hasil belajar yang harus dicapai. (komponen CTL: refleksi).

Pada siklus I dilakukan tiga kali pertemua, setelah pertemuan ketiga berakhir, siswa diberi tes menulis cerpen. Setelah hasil tes dievaluasi ternyata hasilnya belajar siswa belum memenuhi criteria ketuntasan yang ingin dicapai, maka dilanjutkan pada siklus II. Pada 
siklus II juga dilakukan tiga kali pertemuan dan diakhiri dengan tes menulis cerpen. Pada siklus ini hasil belajar siswa sudah menunjukkan ketercapaian kriteria ketuntasan belajar yang

\section{PENUTUP}

1. Penerapan Pembelajaran CTL dapat digunakan untuk meningkatkan hasil belajar menulis cerpen siswa.

2. Aktivitas siswa dalam belajar semakin meningkat/ semakin baik dengan penerapan pembelajaran CTL.

3. Penerapan pembelajaran CTL dapat menjadikan suasana belajar semakin aktif, kreatif dan tidak membosankan.

\section{DAFTAR PUSTAKA}

Anderson, L.W, \& David, R. K. (2001). A Taxonomy for Learning, Teaching, and assessing: A Revision of Bloom' Taxonomy of Educational objectives. New York: Addison Wesley Longman, Inc

Ausubel, D.P. (1968). The Psychology of Meaningful Verbal Learning. New York: Grune and Straton

Bruner, J. (1977). The Process Of Education. Cambridge: Harvard University Press

Depdiknas. (2002). Kurikulum Berbasis Kompetensi (KBK). Jakarta:Depdiknas

Depdiknas. (2003). Pendekatan Kontekstual (CTL). Jakarta: Ditjen Didasmen

Depdiknas. (2006). Silabus Mata Pelajaran pendidikan Bahasa Indonesia. Jakarta: Depdiknas

Gagne, R.M. (1977). The Condition of Learning. New York: Halt Rinerhart and Winston telah ditentukan sehingga tidak dilanjutkan pada siklus berikutnya.

Johnson, E.B. (2002). Contextual Teaching and Learning. California:Corwin Press

Johnson, B.E. (2010). CTL, Contextual Teaching \& Learning. Terj. Ibnu Setiawan. Jakarta: Kaifa

Muliono, A, dkk. (1990). Kamus Besar Bahasa Indonesia. Jakarta: Balai Pustaka

Komalasari, K. (2010). Pembelajaran Kontekstual konsep dan aplikasi. Bandung: Refika Aditama

Kosasih, E. (2004). Kompetensi Ketatabahasaan dan Kesusastraan. Jakarta: Yrama Widya

Miles, M.B, \& Huberman, A.M. (1992). Qualitative Data Analysis: a sourcebook of a new methods. SAGE: Baverly Hills

Nasution, S. (1989). Kurikulum dan Pengajaran. Bandung: bina Aksara

Piaget, J. (1967). Six Psychology Studies. New York: Vintage Book

Reigeluth, M. C. (1983). Instructionnal Design Theories and Models: An Overview Of Their Current Status. London: Lawrence Erlbaum Associates

Sanjaya, W. (2010). Strategi Pembelajaran Berorientasi Standar Proses Pendidikan. Jakarta: Prenada Media

Semi, A. (1988). Anatomi Sastra. Padang: Angkasa Raya

Vygotsky, L.S. (1978). Mind in Society. Cambridge: Harvard University 